\title{
Corporate Governance Practices and Audit Quality: An Empirical Study of the Listed Companies in Egypt
}

\author{
Mohamed Moustafa Soliman, and Mohamed Abd Elsalam
}

\begin{abstract}
Recent financial international scandals around the world have led to a number of investigations into the effectiveness of corporate governance practices and audit quality. Although evidence of corporate governance practices and audit quality exists from developed economies, very scanty studies have been conducted in Egypt where corporate governance is just evolving. Therefore, this study provides evidence on the effectiveness of corporate governance practices and audit quality from a developing country. The data for analysis are gathered from the top 50 most active companies in the Egyptian Stock Exchange, covering the three year period 2007-2009. Logistic regression was used in investigating the questions that were raised in the study. Findings from the study show that board independence; CEO duality and audit committees significantly have relationship with audit quality. The results also, indicate that institutional investor and managerial ownership have no significantly relationship with audit quality. Evidence also exist that size of the company; complexity and business leverage are important factors in audit quality for companies quoted on the Egypt Stock Exchange.
\end{abstract}

Keywords - Corporate governance, Boards of directors, corporate ownership, Audit Committees, Audit quality, and Egypt.

\section{INTRODUCTION}

$\mathrm{T}$ HE weakness of corporate governance is perhaps the most important factor blamed for the corporate failure consequences from the economics and corporate crises [1]. There is much that can be done to improve the integrity of financial reporting through greater accountability, the restoration of resources devoted to audit function, and better corporate governance policies [2]. Previous research shows that there has been much debate over audit quality. Reference [3] defines audit quality as the probability that the auditor will both detect and report a breach in the contract to provide fair accounting information. However, recent empirical researchers suggest that big audit firms guarantee audit quality. Reference [4] found that the firms audited by Big 4 had lower discretionary accruals in the United States than the firms audited by Non-Big 4. In summary, audit quality is associated to the Big 4 brand name.

The literature adequately identifies some aspects of the motivations behind auditor choice decisions but there are many significant shortcomings in the extant literature. First, is

M. M. Soliman is with the Arab Academy for Science \& Technology, College of Management \& Technology, Alexandria, Egypt (phone: 002-0111420-7070; fax: 00203-5566-072; e-mail: Mohamed.soliman@ aast.edu).

M. R. Abd Elsalam is with the Arab Academy for Science \& Technology, College of Management \& Technology, Alexandria, Egypt (phone: 002-0122230-0438; fax: 00203-5566-072; e-mail: raghebmm@ aast.edu). that the literature is centered mainly on developed capital markets in the US and Europe, as a result, there is no knowledge of the auditor choice dynamics in a developing country context where capital markets are still underdeveloped, equity markets are still not considered a primary source of raising corporate finance, the auditing profession is still maturing, and the audit services markets is not as densely concentrated as such markets are in developed countries. Second, the literature focuses primarily on explaining why and when firms choose big auditors. However, it falls short in answering who hires a big auditor. In other words, it does not explain the firm characteristics that may explain the choice of auditor. Third, the existing literature with the exception of [5], and, to some extent, [6], does not link auditor choice to firm corporate governance attributes.

The purpose of this study is to examine the impact of corporate governance practices on audit quality in Egypt. In fact Egypt, as one of the emerging or transition economies, is a unique case. Egypt, among others, responded to the growing attention surrounding corporate governance by reforming the Egypt Code of Corporate Governance: Guidelines and Standards in October 2005. The rules included in this code focus on various aspects of corporate governance, especially boards of directors, audit committees, internal audit departments, external auditors, disclosure of social policies and avoiding conflicts of interest. The main difference between corporate governance environment in Egypt and other developed countries - especially the USA - is that the corporate governance rules included in the Egypt Code of Corporate Governance: Guidelines and Standards are neither mandatory nor legally binding. Rather, the purpose of these rules is to promote responsible and transparent behavior in managing corporations according to international best practices and means that strike equilibrium between various parties' interests [7]. In an institutional setting where the adoption and monitoring of corporate governance practices is not mandatory and lacks legislative force, such as Egypt, it is not clear how auditors would react to client's voluntary adoption of corporate governance practices [8]

The remainder of this paper is organized as follows: Section II discusses the relevant literature including board independence, CEO duality, ownership structure, audit committees and audit quality. The methodology adopted to lend empirical weight to the findings was outlined in Section III. Section IV provides the results while Section V concludes the paper. 


\section{LiteratURE REVIEW AND HyPOTHESES DEVELOPMENT}

\section{A. Overview of Audit Quality}

The various changes in accounting, financial reporting and auditing were all designed to provide protection to investors. This is being achieved by imposing a duty of accountability upon the managers of a company [9]. In essence, auditing is used to provide the needed assurance for investors when relying on audited financial statements. More precisely, the role of auditing is to reduce information asymmetry on accounting numbers, and to minimize the residual loss resulting from managers' opportunism in financial reporting. Effective and perceived qualities (usually designated as apparent quality) are necessary for auditing to produce beneficial effects as a monitoring device [1]. The perceived audit quality by financial statements users is at least as important as the effective audit quality.

According to previous literature the size of the auditor can be considered as subrogate of the audit quality [5], [10], [11], [12] and [6]. Reference [14] assert that larger audit firms are better than smaller audit firms at detecting errors because they have greater resources at their disposal and can attract employees with superior skills and experience. Consequently, larger firms are able to conduct their audits to a higher standard than smaller firms.

\section{B. Board Composition and Audit Quality}

The board of directors assumes an important role in corporate governance. Owing to the separation of corporate management and ownership, boards exist to protect the interests of shareholders [14] and [7]. The board of directors is charged with monitoring and disciplining senior management, and therefore assuring the quality of financial reporting. Several studies [15], [16] and [12] provide evidence regarding the importance of the role of the board of directors in monitoring financial reporting, and therefore mitigating the manipulation of accounting information.

The linkage between the board and the quality of audit services performed may be formal or informal. In terms of formal linkage, the board of directors typically collaborates with management in selecting the external auditor, often subject to shareholder ratification [1]. Since the auditor is to look to the board as its client, it is reasonable to expect the board to review the overall planned audit scope and proposed audit fee [17] and [18]. The board also may influence audit quality through informal means. The board's commitment to vigilant oversight may signal to management and the auditor that the expectations placed on the audit firm are very high. If the auditor understands that the client (that is, the board) is particularly of high quality and demanding, the auditor may perform a higher-quality audit so as not to disappoint the client and jeopardize the relationship. Studies of references [19] and [20] found that the proportion of non-executive directors had a significant positive impact on audit quality. They suggested that non-executive directors encouraged more intensive audits as a complement to their own monitoring role while the reduction in agency costs expected through significant managerial ownership resulted in a reduced need for intensive auditing. Therefore, this lead to the following hypothesis:

H1: There is a significant positive relationship between non-executive Board of Directors and audit quality.

\section{CEO Duality and Audit Quality}

This study also intended to discover the relationship between the CEO duality and audit quality. The CEO duality refers to non-separation of roles between Chief Executive Officer (CEO) and the Chairman of the board. In the normal situation, boards with CEO duality are perceived ineffective because a conflict of interest may arise. This is often attributed to the nature of family owned business in developing countries. Reference [21] posits that large companies that have separate persons for both functions normally trade at higher price and have higher return on assets and cost efficiency ratios [22]. Also, reference [23] believes that duality of the CEO and chairman roles will improve the mechanisms of monitoring management performance, thereby increasing the possibility of choosing a larger audit firm. Therefore, this lead to the following hypothesis:

$H$ 2: There is a significant negative relationship between CEO duality and audit quality.

\section{Ownership Structure and Audit Quality}

The relationship between outside shareholders and managers is marked by moral hazard and opportunism, which result from information asymmetry [1]. It is assumed that institutional investors have more influence than other individual investors. With the high portion of ownership, institutional ownership has the importance of monitoring role in the process auditing. It is rational that institutional investors demand high quality information from the company. Reference [11] observed that the greater the level of institutional ownership, the more likely it is that a firm purchases audit services from large audit firm in order to ensure high audit quality. Reference [24] found that diffused institutional ownership was significantly and positively related to audit fees. It is expected that the portion of institutional ownership will have impact on audit quality of the company. Also, reference [25] believes that the growth of institutional ownership will increase demands for audit services with higher quality.

Based on existing literature, institutional investors, including banks, insurance companies, pension fund associations, investment companies, and others, are institutions that buy and sell large amounts of securities; and because of their right to vote in annual general meetings, they directly affect the managerial decisions of investees [11]. Therefore the hypothesis is that growth in the ownership percentage of institutional investors will increase the demand for high-quality audit services and the plausibility of choosing big audit firms. 
It is believed that an increase in the managers' ownership percentage through a reduction of information asymmetry will decrease the conflict of interest between managers and shareholders [26] and [27]. Reference [26] investigated the relation between ownership structure and demand for audit quality by using information taken from 478 Finnish firms from 2000 to 2006. The results show that an increase in managerial ownership decreases the likelihood that the firm will engage a Big4 auditor, but it has no impact on the demand for certified auditors. Their findings also suggest a nonlinear connection between managerial ownership and demand for audit quality in terms of Big4 audits. Further, they find that the probability of choosing a Big4 auditor increases with an increase in firm size and the presence of foreign sales. According to reference [27], increasing the managerial ownership percentage will decrease the possibility of choosing a larger audit firm. Therefore, this lead to the following hypotheses:

H3: There is significant positive relationship between institutional ownership and audit quality.

H4: There is significant negative relationship between managerial ownership and audit quality.

\section{E. Audit Committees and Audit Quality}

Audit committees are increasingly being seen as one of the more effective corporate governance levers used in both the Anglo-Saxon and Japan-German models of corporate governance. Since Cadbury (1992) Committee recommendations, all the so-called corporate governance best practice codes recommend institution of audit committees in order to improve monitoring quality of both internal and external audits. The audit committee is responsible for recommending the selection of an external auditor, ensuring the soundness and quality of internal accounting and control practices, and monitoring the external auditor's independence from senior management [15]. Reference [28] suggested that the existence of an audit committee was associated with a lower incidence of shareholder litigation alleging management fraud, quarterly earnings restatements, SEC enforcement actions, illegal acts, and auditor turnover due to accounting disagreement with management.

In addition, reference [29] suggested that interaction between external auditors and the audit committee can potentially improve the quality of information provided to the external stakeholders. In the context of Egypt, according to the Egyptian Code of Corporate Governance (2005), the board should establish an audit committee with at least three independent directors or more. Therefore, this lead to the following hypothesis:

H5: There is a significant positive relationship between existence of audit committees and audit quality

\section{F. Corporate Governance and Auditing Profession in Egypt}

On October 2005, the Institute of Directors an agency authorized by the ministry of investment in Egypt, issued the Egypt Code of Corporate Governance: Guidelines and Standards, which includes a number of rules to be considered in addition to the corporate-related provisions stated under other laws (i.e. Law 159/1981 of shareholding joint stock, partnerships, and limited liability companies, and Capital Market Authority Law 95/1992, which regulates companies listed on the Egyptian Stock Exchange). The rules included in this Code focus on various aspects of corporate governance, especially general assembly, boards of directors, internal audit departments, external auditors, disclosure of social policies, and avoiding conflicts of interest.

Regarding auditing profession, Egypt has a combined structure of the auditing firms. All the major international auditing firms have a presence in Egypt in addition to wellestablished local auditing firms. It might be expected that international auditing firms working in Egypt would be more familiar with IAS including parts of the IAS which are not publicly available in Arabic. As a result, it is expected that Egyptian companies audited by one of the international auditing firms will comply more closely with the IAS. KPMG, Ernst and Young, Deloitte Touche Tohmatsu, and Price Waterhouse Coopers are the major international accountancy and legal firms with local partnership.

Almost all ISA are applicable in Egypt. Auditors are required to follow the six Egyptian auditing standards that relate to an auditor's report, and any ISA that relates to other aspects of the auditing process. Knowledge deficiencies of most practitioners by ISA in practice restrict ensuring sound auditing practice. Although large auditing firms have greater competence to provide high auditing quality, compliance with the applicable auditing standards is not always ensured: in this respect the large firms differ from the small firms. References [30] noticed in Egypt that international auditing firms, in most cases, stated that the financial statements were prepared according to the IAS. In many cases, international auditing firms referred to compliance with IAS, but not the ISA. In contrast, local auditing firms, in most cases, stated that the financial statements were prepared according to Generally Accepted Accounting Principles (GAAP) without giving any further explanation of what the phrase meant.

\section{MethodOLOGY}

\section{A. Sample Selection}

We selected the Egyptian companies from amongst the top 50 most active-traded companies listed in the Egyptian Stock Exchange over the period 2007-2009. The banking and insurance sectors are not included in this study as the characteristics of these firms are different from the firms in other industrial sectors in terms of financial statement profitability measures and liquidity assessment. Also, they were specialized in nature and were subject to different regulations, tax and accounting rules [31]. This gave us a 
sample of 42 firms. As no relevant Data Stream exists in Egypt, the annual reports and the Board of Directors reports, covering the three year period 2007-2009, were purchased from the Egyptian Company for Information Dissemination (EGID) to extract the information on the variables needed to test each of our hypotheses.

\section{B. Definition of Variables}

The dependent variable is audit quality (AQ). This variable is dichotomous in nature. Size of audit firm (big 4 and non-big 4) was used as proxy for audit quality [32] and [27]. Audit quality was set equal to one (1) if the information obtained from companies audited reports show that it is audited by one of the "big 4" audit firms, otherwise zero (0). This operationalization follows the approach used in [11] and [9], where big audit firms are assumed to have quality audit services than other smaller audit firms.

The choice of the independent variables was informed by previous studies [32], [12], [20], and [32]. Board independence (BI) was measured through the composition of non-executives in the board of directors in form of percentage. The variable of CEO duality (CD) was a dichotomous variable that operated as one (1) if the position of Chairman and Chief Executive Officer is occupied by same person and zero (0) if otherwise. Furthermore, institutional investors (IO) were measured using percentage of shares owned in relation to the issued capital of the company. The percentage of shareholding for insiders, managerial ownership (MO), is computed as the number of shares held by corporate insiders divided by the number of shares of outstanding common stock. A dummy variable, labeled (AC), is used whereby a value of 1 is awarded to firms having audit committees and zero otherwise. The inclusion of other variables like size of the company (SZ), business complexity (CM) and leverage of the company (LE) was based on the findings of [11] and [32]. The studies noted that these variables have significant relationships with audit quality. The size of the company was measured by taking the logarithm of the total firm assets while business complexity was measured by the summation of total accounts receivable and total inventory divided by total asset. Finally, firm's financial leverage, was measured as the ratio of debt to total assets.

There are a number of companies that were in the top 50 most active-traded companies listed in the Egyptian Stock Exchange in 2007 that are not in 2009 raising concerns regarding the effect that non-surviving firms have on the results. To control the effect of non-survivorship firms on the results, a dumpy variable (SU) is created which is equal to 1 if the firm is continuously present in all the years of the sampling period from 2007 to 2009 , otherwise it is equal to 0 .

\section{Empirical Model}

The hypotheses formulated for this study were tested with the use of logistic regression. This was used to examine the relationship between dependent and independent variables. The logistic regression for this study takes the form:

$$
\begin{aligned}
& \mathrm{AQ}=\beta 0+\beta 1 \mathrm{BI}+\beta 2 \mathrm{CD}+\beta 3 \mathrm{IO}+\beta 4 \mathrm{MO}+\beta 5 \mathrm{AC}+\beta 6 \mathrm{SZ} \\
& + \\
& \beta 7 \mathrm{CM}+\beta 8 \mathrm{LE}+\beta 9 \mathrm{SU}+\varepsilon
\end{aligned}
$$

Where:

$\mathrm{AQ}$, audit quality; $\mathrm{BI}$, board independence; $\mathrm{CD}$, CEO duality; IO, institutional investors; MO, managerial ownership; $\mathrm{AC}$, audit committees; SZ, size of the company; CM, business complexity; LE, firm's financial leverage; SU, firm survival.

\section{Results AND Discussion}

\section{A. Descriptive Statistics}

This section of the study is devoted to presenting the results of the analysis performed on the data collected to test the propositions made in the study and answer the research questions. Analyses were carried out with the aid of the Statistical Package for Social Sciences (SPSS). Table I provides the minimum, maximum, mean, and standard deviation of the variables in the study. The results reveal that (31\%) of companies sampled are audited by the big 4 audit firms. Regarding the composition of the board of directors, the average ratio of independent directors is (71\%), with a maximum of $(87 \%)$ and a minimum of $(50 \%)$.

As far as CEO duality is concerned, our results show that $(88.1 \%)$ of companies in the sample have not separated the role of CEO and board chairperson. In general, therefore, Egyptian boards seem to be dominated by one person. With regard to the percentage of institutional investors, the results indicate that the average of $(52 \%)$ of shares owned by institutional investors in relation to the issued capital of the companies.

TABLE I

DESCRIPTIVE STATISTICS

\begin{tabular}{|l|c|c|c|c|}
\hline \multicolumn{1}{|c|}{ Variable } & Min & Max & Mean & Std. Dev. \\
\hline Audit Quality & 0.00 & 1.00 & .3095 & 0.46790 \\
Board Independence & 0.50 & .87 & .7188 & 0.10816 \\
CEO Duality & 0.00 & 1.00 & .8810 & 0.32777 \\
Institutional Investors & 0.100 & .95 & .5243 & 0.30141 \\
Managerial Ownership & 0.00 & .51 & .0867 & 0.16412 \\
Audit Committees & 0.00 & 1.00 & .4286 & 0.50087 \\
Size of the Company & 9.96 & 17.82 & 13.92 & 2.6087 \\
Business Complexity & 0.00 & .46 & .1560 & 0.15277 \\
Financial Leverage & -0.12 & .98 & .3567 & 0.31554 \\
Firm Survival & 0.00 & 1.00 & .3095 & 0.46790 \\
\hline
\end{tabular}

\section{B. Results of Logistic Regression Model}

The analysis of logistic regression was done to test the hypotheses proposed for this study. Table II represents a correlation matrix for the selected variables; The Pearson's correlation matrix shows that the degree of correlation between the independent variables is either low or moderate, which suggests the absence of multicollinearity between independent variables. As suggested by [33], the Pearson's $R$ between each pair of independent variables should not exceed 0.80 ; otherwise, independent variables with a coefficient in excess of 0.80 may be suspected of exhibiting multicollinearity. The highest correlation as disclosed in the 
table is between audit quality (AQ) and audit committees (AC) with the amount of 0.778 . This confirms that there is no multicollinearity among the variables.

TABLE II

CORRELATION COEFFICIENTS MATRIX OF THE VARIABLES USED IN THE STUDY

\begin{tabular}{|c|c|c|c|c|c|c|c|c|c|}
\hline & AQ & BI & CD & IO & MO & AC & SZ & CM & LE \\
\hline AQ & 1 & & & & & & & & \\
\hline BI & .349 & 1 & & & & & & & \\
\hline CD & -.520 & .237 & 1 & & & & & & \\
\hline IO & -.554 & .442 & .524 & 1 & & & & & \\
\hline MO & .507 & .0269 & -.678 & -.640 & 1 & & & & \\
\hline AC & .778 & .223 & -.424 & .123 & .391 & 1 & & & \\
\hline SZ & .428 & -.607 & -.555 & -.291 & .528 & .384 & 1 & & \\
\hline CM & .345 & .129 & .308 & .036 & -.145 & -.429 & -.472 & 1 & \\
\hline LE & .555 & .139 & -.322 & -.249 & .405 & .488 & -.111 & -.333 & 1 \\
\hline
\end{tabular}

This section of the results, the multivariate analysis, is devoted to provide information about the regression model. Table III shows the results of the regression analysis. The results show the explanatory power of the model as measured by the R Square and adjusted R Square. The later, the adjusted $\mathrm{R}$ Square provides a better estimation of the true population value, especially with a small sample [34]. The value of the adjusted R Square in the current study is $84.3 \%$. Therefore, the model adequately describes the data.

As far as the corporate governance variables are concerned, board independence has a positively significant association with audit quality, p-value $<0.05$, supporting Hypothesis 1 . This finding is consistent with the finding of [19] and suggests that independent directors have a positive impact on audit quality by requiring more extensive auditing. The result also suggests that independent board of directors seek to purchase differentially higher-quality audit services in order to protect their reputation capital and to promote shareholders' interests.

TABLE III

THE REGRESSION RESULTS OF THE VARIABLES USED IN THE STUDY

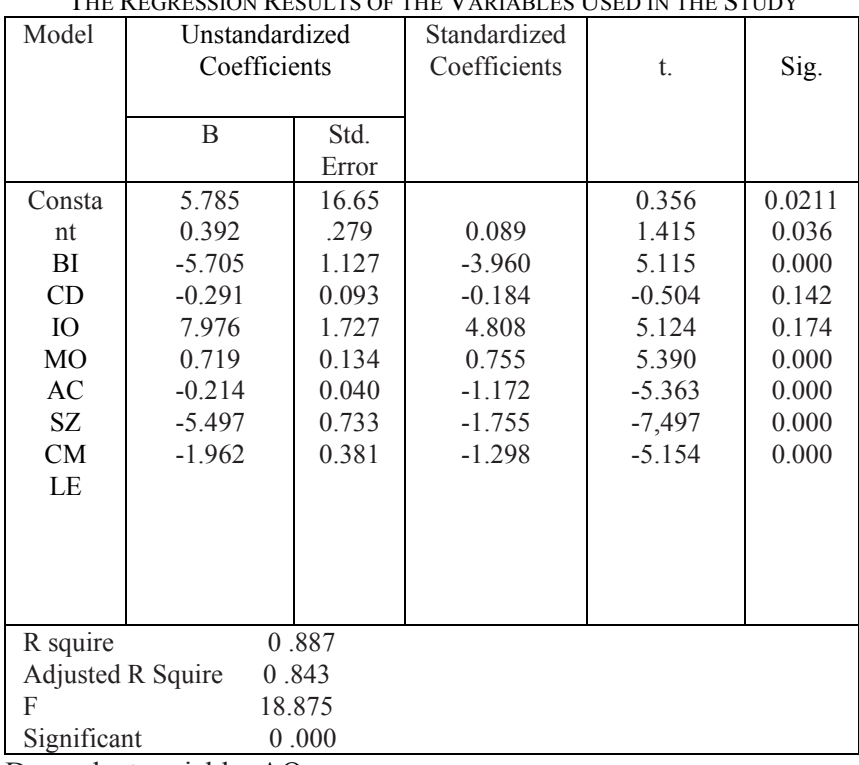

Dependent variable: $\mathrm{AQ}$
Our second hypothesis deals with the CEO duality. Empirical results show that there is a negative and statistically significant link between CEO duality and audit quality, pvalue $<0.05$, supporting Hypothesis 2 . This is often attributed to the nature of family owned business in developing countries. The result also suggests from Table III that institutional investor (IO) and managerial ownership (MO) have no significant correlation with audit quality, with a pvalue of 0.142 , and 0.174 respectively, and hence we do not find support for Hypothesis 3 and 4. This finding is consistent with the finding of [26], [27] and [1]. Also, empirical results show that there is a positive and statistically significant link between audit committee and audit quality, p-value $<0.05$, supporting Hypothesis 5. This finding is consistent with the finding of [15] and suggests that audit committee is responsible for recommending the selection of an external auditor, ensuring the soundness and quality of internal accounting and control practices, and monitoring the external auditor's independence from senior management.

Table III also, shows results from control variables size of the company (SZ), business complexity (CM) and leverage of the company (LE), have positive and statistically significant link relationship with audit quality, $p$-value $<0.05$. This finding is consistent with the finding of [11] and [33].

\section{CONCLUSION}

The purpose of this study is to examine the impact of corporate governance practices on audit quality in Egypt. Results from the study indicate that board independence; CEO duality and audit committees significantly have relationship with audit quality. The results also, indicate that institutional investor and managerial ownership have no significant correlation with audit quality. However, all the other variables that were not found to have significant relationship still had correlation with audit quality at certain levels

The results of the study have significant implications for regulators and researchers in Egypt. First, the results mentioned above signify the importance of corporate governance mechanisms in enhancing the quality of financial reporting process. Thus, these results should be considered by regulators in Egypt in order to begin the necessary actions for legally pending the Egypt Code of Corporate Governance, issued on October 2005 by the Ministry of Investment and as yet still voluntary.

Limitation of the study is that this study is using a small sample of 42 companies. This sample may be small in size and, by construction, composed of the most active Egyptian listed companies and thus may not be representative of the population of Egyptian firms, consequently, caution should be considered in evaluating the results. Thus, it might have been better to look at companies from a wider range.

\section{REFERENCES}

[1] Adeyemi, S. B, and Temitope O. F., "Audit Quality, Corporate Governance and Firm Characteristics in Nigeria", International Journal of Business and Management, Vol. 5, No. 5, P. 169- 179, 2010. 
[2] Saudagaran, S. M., "The Accounting World Post-Enron, Tyco, Vivendi, Worldcom, Xerox: Reflections on Being Part of the Solution", Malaysian Accounting Review, Vol. 2, No.1, P. 2-12, 2003.

[3] DeAngelo, L.E., "Auditor size and audit quality", Journal of Accounting and Economics, Vol. 3, No. 3, pp. 99-183, 1981.

[4] Becker, C., Defond, M., Jiambalvo, J., and K. Subramanyam, "The effect of audit quality on earnings management", Contemporary accounting research, Vol.15, pp.1-24, 1998.

[5] Piot, C., "Auditor Reputation and Model of Governance: A Comparison of France, Germany and Canada", International Journal of Auditing, Vol. 9, P. 21-44, 2005.

[6] Fan, J. P. H. and T. J. Wong, "Do External Auditors Perform a Corporate Governance Role in Emerging Markets? Evidence from East Asia", Journal of Accounting Research, Vol. 43, No. 1, P. 35-72, 2004.

[7] Ebaid, I. E.," Corporate governance practices and auditor's client acceptance decision: empirical evidence from Egypt", Corporate Governance, Vol. 11, No. 2, P. 171-183, 2011.

[8] Sharma, D.S., Boo, E. and Sharma, V.D. "The impact of non-mandatory corporate governance on auditors' client acceptance, risk and planning judgments", Accounting and Business Research, Vol. 38 No. 2, p. 105 20, 2008.

[9] Craswell, A., J., Francis, and S., Taylor, "Auditor brand name reputations and industry specializations", Journal of Accounting and Economics, Vol. 20, No. 3, pp. 297-322, 1995.

[10] Sainty, B.J., Taylor, G.K. and Williams, D.D., "Investor dissatisfaction toward auditors", Journal of Accounting, Auditing and Finance, Vol.17, No.2, 2002.

[11] Kane, G. D., and. U. Velury, "The Role of Institutional Ownership in the Market for Auditing Services: An Empirical Envestigation", Journal of Business Research, Vol. 57, (September), pp. 976-983, 2004.

[12] Carcello, J.V., and Nagy. A.L., "Client size, auditor specialization and fraudulent financial reporting”, Managerial Auditing Journal, Vol.19, No.5, 2004.

[13] Simunic, D.A. and Stein, M.T., "Product Differentiation in Auditing: Auditor Choice in the Market for Unseasoned New Issues", Canadian Certified General Accountants' Research Foundation Monograph, 1987.

[14] DeZoort, F.T., Hermanson, D.R., Archambeault, D.S. and Reed, S.A. "Audit committee effectiveness: a synthesis of the empirical audit committee literature", Journal of Accounting Literature, Vol. 21, p. 38$75,2002$.

[15] Anderson, R.C., Mansi, S.A. and Reeb, D.M., "American Institute of Certified Public Accountants AICPA professional standards, Statement on Quality Control Standards, American Institute of Certified Public Accountants, New York', Journal of Accounting and Economics, Vol. 37 No. 2, p. 315-42, 2004.

[16] Klein, A., "Audit committee, board of directors characteristics, and earnings management', Journal of Accounting and Economics, Vol. 33 No. 2, p. 375-400, 2002.

[17] Blue Ribbon Committee, Report and recommendations of the Blue Ribbon Committee on improving the effectiveness of corporate audit committee, New York: NYSE and NASD, 1999.

[18] Public Oversight Board. Strengthening the professionalism of the independent auditor. Stamford, CT: POB, 1994.

[19] O'Sullivan, N., "The impact of board composition and ownership on audit quality: evidence from large UK companies", The British Accounting Review, Vol. 32, No.4, P.397- 414, 2000.

[20] Salleh, Z., Stewart, J., \& Manson, S., "The Impact of Board Composition and Ethnicity on Audit Quality: Evidence from Malaysian Companies", Malaysian Accounting Review, Vol. 5, No. 2, P. 61-83, 2006.

[21] Yermack, D., "Higher Market Valuation of Companies with Small Boards of Directors", Journal of Financial Economics, Vol.40, No. 2, P 185-212, 1996.

[22] Pi, L., \& Timme, S., "Corporate Control and Bank Efficiency", Journal of Banking and Finance, Vol. 17, No.2, P. 515-530, 1993.

[23] Lin, Z. J., and M. Liu, "The Impact of Corporate Governance on Auditor Choice: Evidence from China", Journal of International Accounting, Auditing and Taxation, Vol. 18, No. 1, pp. 44-59, 2009.

[24] Mitra, S., Hossain, M., \& Deis, D.R., "The empirical relationship between ownership characteristics and audit fees", Rev Quant Finance Acc, Vol. 28, P. 257-285, 2007.

[25] Chan, K. H., Lin. K. Z., and F. Zhang, "On the Association between Changes in Corporate Ownership and Changes in Auditor Quality in a
Transitional Economy", Journal of International Accounting Research, Vol. 6, No. 1, pp. 19-36, 2007.

[26] Niskanen, M., Karjalainen, J., and J. Niskanen, "Demand for Audit Quality in Small Private Firms: Evidence on Ownership Effects", Available at: http://ssrn.com/abstract=1324599. 2009.

[27] Mahdavi, G., Mohammed, M., Fahime, E. \& Mehdi, S. "The Impact of Corporate Governance on Auditor Choice", International Research Journal of Finance and Economics, Vol. 68, P. 129-139. 2011.

[28] McMullen, D.A., "Audit committee performance: an investigation of the consequences associated with audit committees", Auditing: A Journal of Practice \& Theory, Vol. 15 No. 1, pp. 1-28, 1996.

[29] Mitchell, V. Z., Singh, H.and Singh, I. "Association between independent audit committee members' human-resource features and underpricing", Journal of Human Resource Costing \& Accounting. Vol. 12 No. 3, P. 179-212, 2008.

[30] Abd-Elsalam, O.H., \& Weetman, P., "Introducing International Accounting Standards to an Emerging Capital Market: Relative Familiarity and Language effect in Egypt", Journal of International Accounting, Auditing \& Taxation, Vol.12, p: 63-84, 2003.

[31] Zeitun, R. and Tian, G., "Does ownership affect a firm's performance and default risk in Jordan?", Corporate Governance, Vol.7 No. 1, P. 6682, 2007.

[32] Beasley, M. S., "An empirical analysis of the relation between the board of director composition and financial statement fraud". Accounting Review, Vol. 71, No.10, P. 443-465, 1996.

[33] Wan, Z.W.A., Shahnaz, I., \& Nurasyikin, J., "The impact of board composition, ownership and CEO duality on audit quality". Malaysian Accounting Review, Vol. 7, No. 2, P. 1-22, 2008.

[34] Tabachnick, B \& Fidell, L., Using multivariate statistics, 3rd edition, New York, Harper Collins, 1996. 